\title{
At the Intersection of Chieftainship and Constitutional Government: Some Comparisons from Micronesia
}

À l'intersection de la chefferie et du gouvernement constitutionnel : quelques comparaisons de Micronésie

\section{Glenn Petersen}

\section{OpenEdition}

Journals

Electronic version

URL: http://journals.openedition.org/jso/7434

DOI: $10.4000 /$ jso.7434

ISSN: $1760-7256$

Publisher

Société des océanistes

Printed version

Date of publication: 15 December 2015

Number of pages: $255-265$

ISBN: 978-2-85430-126-7

ISSN: 0300-953x

\section{Electronic reference}

Glenn Petersen, « At the Intersection of Chieftainship and Constitutional Government: Some Comparisons from Micronesia », Journal de la Société des Océanistes [Online], 141 | juillet-décembre 2015, Online since 15 December 2017, connection on 02 May 2019. URL : http:// journals.openedition.org/jso/7434; DOI : 10.4000/jso.7434 


\title{
At the Intersection of Chieftainship and Constitutional Government: Some Comparisons from Micronesia
}

by

\author{
Glenn PETERSEN*
}

\begin{abstract}
Indigenous Micronesian political forms closely parallel those of eastern Melanesian and Polynesian societies. Chieftainship integrates aspects of land tenure, kin groupings, status hierarchy, and ideologies of the supernatural. Because so many aspects of social and political economy meet in these institutions, chiefly politics have traditionally been responsive to popular pressures; there is in fact, if not necessarily in myth, very little that is autocratic about them. The primary debate in the Federated States of Micronesia has not been about the importance of chieftainship, but whether the people are better served by including chiefs within their constitutional government or keeping them outside it, where it is believed they can more effectively exercise the checks and balances the people wish to maintain.
\end{abstract}

KEYwords: Chieftainship, constitutional government, Federated States of Micronesia

Though Micronesian societies' traditional governments have their roots in cultural history shared with Fiji and Polynesia, they do not attract much attention. This is unfortunate, because there is much to be learned from Micronesians' experiences integrating the dynamics of chieftainship with parliamentary rule. My aim here is to describe key aspects of traditional Micronesian polities, to explore some of the reasons why Micronesians have opted to retain these, and to challenge claims that such traditional forms and practices are inherently incompatible with

\section{RÉSUMÉ}

Les formes politiques indigènes de Micronésie sont très proches de celles des sociétés de Polynésie et de Mélanésie de l'est. $L a$ chefferie intègre certains aspects de la propriété foncière, des groupements de parenté, des statuts hiérarchiques et des idéologies de la surnature. Dans la mesure où ces institutions sont à la croisée de tant d'aspects de l'économie sociale et politique, les politiques menées par les chefs tendent, traditionnellement, à tenir compte des pressions populaires; quoi quien dise le mythe, dans les faits, elles ne sont que très marginalement autocratiques. Le débat central parmi les États fédérés de Micronésie ne concerne donc pas l'importance de la chefferie, mais la question de savoir si le peuple a intérêt à ce que le gouvernement constitutionnel inclut les chefs, ou sil vaut mieux les en exclure, partant du principe quill sont mieux placés pour garantir le contrôle et le contre-point que le peuple souhaite maintenir.

MotS-CLÉs : chefferie, governement constitutionnel, États fédérés de Micronésie

European-based socio-political forms. There just may be some profit in comparing Micronesian responses to the dilemma of maintaining chiefly politics in an era that loudly, if not necessarily scrupulously, shouts out the inevitability of democracy, or at least quasi-democratic forms.

During the course of the first millennium всE, voyaging peoples made the leap from Near Oceania to Remote Oceania, heading out from the Solomon Islands, east (to Fiji, Tonga, and Samoa), south (to what are now known as Vanuatu and New Caledonia), and north (to Pohnpei and Kos- 
rae). There must have been multiple voyages in each direction, conducted by several different but closely related populations, and these peoples carried with them a range of interrelated languages, cultural beliefs, and social practices. The modern populations of Eastern Melanesia, Fiji, Polynesia, and most of Micronesia are descended from these ancestral stocks and for all the apparent differences in their languages, cultures, and societies, they manifest important and fundamental commonalities $^{1}$. The overarching socio-political form scholars refer to as chieftainship thrives everywhere in these islands and plays a central organizing role in the social lives of their peoples.

Each of these societies has undergone not only its own specific historical developments but also experienced ongoing and recurring linkages with the societies of multiple other islands. Because they also share some fundamental precepts and because they must ultimately provide viable governments to their peoples, it possible to point to certain recurring themes. Among these are notions of deep and indelible ties between leaders and land; leaders' status rooted in kin groups; precedence within and between groups based to some extent on seniority of descent; dynamic ties between leaders and the natural and supernatural worlds (often known by some cognate of "mana"); and reciprocal notions that gifts must be given to leaders for both religious and practical reasons and that leaders must bestow gifts on their constituents for similar reasons. There exist everywhere in the region well-developed ideologies of hierarchy or rank, but the behavioral signs of hierarchical organization vary greatly, from quasi-egalitarian to seemingly authoritarian. In all these societies, however, no matter how despotic they seem to be, multiple checks and balances are provided by variant versions of key mythological charters, competition for status within and between kin groups laying claim to chiefly positions, rivalries for local precedence, and the practical exigencies of demography, political and martial skills, and idiosyncrasies of individual personalities.

Many foreign political scientists, as well as some members of these societies, argue that the governmental institutions comprising chieftainship are fundamentally incompatible with the state-organized and more or less democratic political processes introduced into the islands by foreign colonial governments. This perspective seems absurd on its face, since there are not many political processes less democratic than the forcible imposition of foreign rule, but this contradiction has not kept scholars and bureaucrats from decrying the benighted politics of chieftainship as constituting the greatest impediment to the salvation political scientists attribute to the modern nationstate, Westphalian-based international relations, and Grotian political theory. There is perhaps even greater irony in the specter of metropolitan powers insisting on replication of their own political practices as a condition of decolonization.

Underlying my approach here is my sense that in everyday life virtually all systems of politics and government operate at some degree of variance from whatever theoretical frameworks they are supposed to be based upon. ("Utopia", that is, a place where there is absolute coherence between the theory and practice of government, exists, in Thomas More's original sense of the word, "no place"). Contemporary state-organized governments are inherently neither more nor less likely to perform according to theory than chieftainships, and problems attributed to the alleged inefficiencies and inequalities of chieftainship are likely to be the result of conflicts between competing forms of government, rather than the necessary consequence of one type of government or another.

\section{Some elements of Micronesian socio- political organization}

Traditional social life in Micronesia is characterized by the region's dispersed matrilineal clans, which exist virtually everywhere in the $\operatorname{area}^{2}$. As I have demonstrated at length in Traditional Micronesian Societies (Petersen, 2009), these seem to have first taken form on Pohnpei and Kosrae in the eastern Carolines, then diffused to the rest of the Micronesian islands, probably because of the adaptive advantages they confer in a region that is home to the western Pacific's typhoon spawning grounds and beset by ENSO-driven droughts. The dispersed character of the clans means that on each Micronesian island or community are resident subclans and lineages of multiple clans, and each clan has subclans and lineages planted on multiple islands and communities. Ethnological accounts tend to stress Micronesia's matriliny as its key distinction, but it is in fact the dispersed nature of these descent groups that is most salient.

These clans and lineages are in classical ethnological terms "conical" in organization and in fact fit the archetypal model of conical clans, developed by Marshall Sahlins $(1958,1968)$ and refined by Patrick Kirch (1989), even more closely than Polynesia's descent groups. The clans, along with the lineages that constitute them, have multiple functions and characteristics, but for present purposes two of these are of greatest relevance: the ways in which clans that successfully assert settlement

1. Palau and the Marianas were settled from the west a nd Yap probably from the south, but these societies were profoundly affected by influences from the Eastern Carolines (Petersen, 2006).

2. Even Kiribati has clear evidence of matrilineal clans pre-existing more recent influences from Samoa. 
priority on any island or in any community provide chiefs for all the other groups residing there, and ways in which the ambiguities of genealogical seniority promote effective leadership within the ruling lineages and communities.

A fundamental precept of Micronesian life is that the first kin group to settle an area or island thereby establishes title over it. But in Epeli Hau'ofa's sense of a "sea of islands," Micronesia has always been a sea of immigrants, as its characteristic dispersed clan pattern clearly demonstrates. The nature of Micronesian communities reflects the fact that they survive only by creating and maintaining close ties to other islands and communities. This means that even though the first settlers and their descendants claim (and are usually believed to possess) fairly well-established title to the land, they need to attract new members with ties to other places. According to both Micronesian mythology and reality, nearly everyone has come from somewhere else. But after arriving, visiting voyagers can quickly become settlers, even while retaining ties to fellow clan members in the communities from whence they came (which is of course the reason they are encouraged to settle). The primary means of enticing visiting voyagers to settle is to provide them with rights to land. Having received title to the lands they settle, newly arrived groups are made to feel secure enough to remain and to thus share with the resident population the advantages of their ties to other islands and communities.

This is why in virtually all Micronesian societies there exist dual kinds of titles to land, the rights claimed by the first settlers ("residual" rights in Goodenough's 1951 terminology) and the rights claimed by the later occupants who actually reside on and cultivate the land ("provisional" rights). In other words, a community seeks new members precisely because they bring with them ties to other places, ties the original settlers hope to multiply in order to improve their community's security. But because the new settlers bring with them already-existing clan and lineage organization, they possess already-established patterns of hierarchical relations. That is, in order for $\mathrm{Mi}$ cronesian communities to persist and thrive they must incorporate competing organizations.

In each and every Micronesian community there are two cross-cutting forms of chiefly authority. There is the territorial chief, who is head of the kin group - clan or lineage - that claims to have originally settled the land, and then there are also the chiefs of all the other kin groups that have subsequently settled there. Micronesian communities have, almost by definition, multiple chiefs who derive their authority from differing sources, some from the land and some from their kin groups. Simple checks and balances, then, are inherent in the nature of Micronesian socio-political organization.
On the high islands, with much larger (though not necessarily denser) populations than the atolls, hierarchies based on genealogical seniority and settlement priority can become quite elaborate. Smaller, local communities with their own cross-cutting chiefly hierarchies are subsumed into larger paramount chiefdoms that may include dozens of these smaller units, sometimes with intermediate-level groupings as well. Competition among the larger chiefdoms resulted in increasing levels of organization, and additional forms of rank developed, including but by no means limited to specialists of many kinds. On some of the largest islands, including Pohnpei, Yap, and Palau, federations appeared. Moreover, all these communities and societies maintained patterns of councils where, depending on population size and other factors, either the entire adult population or representative leaders from lineages were free to speak their minds. While Micronesian political styles call for low-key discussions in public venues (indeed, Palauans refer to political discourse as "whispering"), the ability to gauge public opinion is considered a vital element of competent leadership, a point to which I shall return.

The multiple and cross-cutting lines of authority in Micronesian communities thus produce an effective series of and checks and balances. These were thoroughly formalized in some societies; on Pohnpei, for instance, there were three parallel lines of chiefly titles within each of the paramount chiefdoms, each with its own source of authority enabling it to confront and challenge the others under certain circumstances.

It is also the case, of course, that violence, on the part of both individuals and groups, had a significant role in Micronesian political life. Stories of assassinations of chiefs are not unusual and served to remind leaders of the dangers that abusive behaviors can pose, as well as threats from rival (especially junior) kinsmen. Moreover, local oral histories, ethnohistoric accounts, and ethnographic reports tell us that warfare was a significant factor in Micronesian life. It is my own sense (Petersen 2014) that the many aspects of martial spirit that run through Micronesian culture - and this is especially seen in the many forms of dance performances that incorporate forms of mock combat - are intended to warn potential foes that a community is able to protect itself at least as much as they are evidence that Micronesian communities spent a good deal of time and energy actually engaged in combat. In many Micronesian societies, war leaders possess rank, status, and authority that is distinct from leaders whose authority is based on genealogical ties to ancestors. Again we encounter the separation of powers, which in turn provides checks and balances.

A much broader point follows from this. Micronesian political rhetoric combines emphases on both humility and the power of leaders. Chiefs are simultaneously accorded the greatest respect and 
expected to behave with true modesty. There are, of course, exceptions to this, but tensions between status and humility are fundamental to nearly every aspect of Micronesian socio-political style.

\section{Seniority}

There is a second way in which Micronesian clan organization shapes the nature of political life and, again, this derives from an older Oceanic pattern. I am referring to the ways in which ambiguities of genealogical seniority promote effective leadership within the ruling lineages and communities. Micronesian political theory stresses the importance of seniority of descent, as is typical of conical clan organization, but precisely because this principle has influence on so many aspects of life it possesses significant potential for doing harm. If chiefly succession were entirely automatic, and birth order was its sole determinant, then communities would face the recurring danger of having incompetent heirs occupying crucial leadership positions. They would find themselves with chiefs unable to guide them, or to listen thoughtfully to wise counsel. While a great many factors determine the actual processes of succession, one fundamental contradiction in the process provides the ambiguity and tension necessary to truly dynamic political life. And that is the ambiguity inherent in Micronesian concepts of seniority.

These concepts depend on competing notions of what in English can be glossed as "older." I have heard Pohnpeians, when pushed beyond customary reticence into asserting a right of authority, say, "Ngehi me laud." They could mean by this "I am senior" or "I am older," meaning either that they are genealogically closer to an apical ancestor or chronologically older than the individuals they aare sserting their claims against. That is, in a matrilineal society there are built-in ambiguities or tensions between an older, genealogically senior woman's younger brothers and her sons. Her brothers are a generation older than their sisters' sons, while at the same time her sons are genealogically senior to their mothers' younger brothers. Each category can legitimately claim to be senior to the other. And despite many claims to the contrary by interested individuals, both methods of reckoning who is senior - genealogy and chronology - are regularly asserted by pretenders to a chiefly title $^{3}$. While this may seem in the abstract to be a somewhat trivial distinction, it is in fact utterly central to much of political life. Because there are almost always several potential successors to an important title as a result of this ambiguity, chiefly succession is often disputed. The ensuing rivalries in turn generate the sorts of competitive practices that flow from the status anxiety Irving Goldman $(1955,1970)$ long ago described in Polynesian societies. Would-be leaders must continually prove themselves; they are rarely entirely comfortable with their claims to titles; and together with close family members and allies they must engage almost ceaselessly in the competitive feasting that characterizes so much of public life.

In Micronesia this status ambiguity is only sometimes a matter of public record, but it plays continually behind the scenes, and in combination with the dual and often ambiguous notions about land tenure it contributes materially to the dynamic character of chieftainship I am describing here.

\section{Land and Political Theory}

Complex webs of ideas, assumptions, and historical traditions shape relations among Micronesian land tenure, lineages, chieftainship, and political life in general. But this richly textured fabric does not, in fact, differ all that much from aspects of European and American political traditions. I turn for a moment to Western political thought in order to provide a context for understanding some of the subtleties of Micronesian life. The era of the English Revolution provides modern political theory with much of its basis for considering relations between property - or more specifically, land - and political life. In Two Treatises of Government John Locke provided both his contemporaries and subsequent generations of thinkers with some timeless arguments regarding the appropriate nature of government. In his first treatise Locke challenged arguments in support of what is now known as "the divine right of kings." This notion held that the legitimacy of the king's rule derived from his authority over all the realm's lands as a consequence of his succession from Adam, to whom God had granted dominion over all the earth. Rather than directly disputing the specific character of a king's antecedents, Locke instead denied that "Property in Land gives a Man Power over the Life of another" and reasoned that "no Man could ever have a just Power over the Life of another, by Right of property in Land or Possessions" (Locke, 1960: 205-206, I.iv, 41-42). In the second treatise Locke developed this principle further, maintaining that

« every Man has a Property in his own Person [...]. The Labour of his Body, and the Work of his Hands, we may say, are properly his. Whatsoever he then removes out of the State that Nature hath provided, and

3. When I first began to encounter significant differences of opinion about who was considered rightful successor to a title, I naively assumed that this was because people no longer understood their own cultural rules. I came in time to understand instead that these differences are what make the system survive and thrive. 
left it in, he hath mixed his Labour with, and joyned it to something that is his own, and thereby makes it his Property. » (Locke, 1960: 328-329, II.v.27)

That is, humans create property by conjoining their own labor with nature.

It is necessary to stress here that there have been periods - eras, in fact - when republican and monarchical principles coexisted, as they also do in many contemporary Pacific island societies. As Pocock's The Machiavellian Moment (1975) fully demonstrates, aspects of both these contrasting outlooks informed western political discourse for centuries. Within a single European society, then, there were competing notions about relationships between government and property. While these are not identical with Micronesian perspectives on connections between chiefly government and property rights, they draw on strikingly similar assumptions: concurrent, competing notions about rights conferred by hereditary succession and by actually working the land.

Similar precepts inform traditional Micronesian society. While the authority and the rights of chiefs are sometimes attributed to conquest (especially in the Marshalls), in general the authority that inheres in a Micronesian chief by virtue of his office is rooted in his descent from ancestors who were the first to occupy or settle an island or place. Almost everywhere we find that a community's leading lineage or clan claims that its legitimacy as the pre-eminent group derives from this settlement priority, and the community's chief is chief by virtue of being head of its leading descent group. The concept of residual title over land bears this out. What is owed to a chief - first fruits, respect, and, in some circumstances and to some degree, obedience - is owed to him because of his group's precedence. The chief's eminence comes because of his status as a senior member of the senior group. Both the importance of seniority of descent and the importance of residual title over the land are cited by nearly every Micronesian when discussing why a chief is a chief, what privileges a chief is due, and what responsibilities encumber him. Whatever disagreements Micronesians may have about what constitutes chieftainship, and about which individual should occupy the office (and there are many), they all know intuitively how and why one is supposed to become a chief.

At the same time, we can see a shared notion that the descent groups that occupy land - the people who work it, improve it, and derive their lives and identities from it - are also its rightful proprietors. And there is a common notion that the land derives its value from the work that a lineage, and more important, its ancestors, has put into developing and improving it, making it productive farmland, keep it yielding a living to those who continue to cultivate it. While the chiefly lineage's claims over land derive from priority of settlement and descent, the claims of lineages residing upon this same land derive from the labor they have invested in it. And although Micronesians readily attest to the chief's authority over the land, they are equally vocal about the lineage's rights over it. A chief cannot alienate a lineage's land - remove it from them or drive them off it - unless there is an overriding consensus within the community that the lineage has done something socially unacceptable or reprehensible to bring this upon themselves, or clearly and repeatedly failed to discharge their acknowledged duties to the chief. As Goodenough notes, in Chuuk there may arise

" a situation in which powerful persons and lineages could take advantage of weaker ones. While this has happened, the entire community is likely to unite against a too frequent offender » (1951: 60)

In short, there are two differing Micronesian concepts regarding land rights, and the nature of Micronesian political thought cannot be understood unless both these viewpoints are comprehended simultaneously. Unfortunately, most of those who have reported on Micronesian chieftainship and land tenure have assumed that the Micronesian statements about chiefly authority and dominion that resonate with European conceptions of the divine rights of kings constitute the totality of the Micronesian perspective. And thus Micronesian chiefs are commonly portrayed as being in possession of rather awesome authority. But closer examination of the dynamics of Micronesian sociopolitical life tends to belie this stereotype. The only way to make sense of this disparity is to recognize the simultaneous existence of these two contrary notions.

Locke's notion in the second treatise was that land became property - was separated out from nature - by the labor of those who worked it, and that property was thus imbued with the personality of those who created it. Land belonged to those who cultivated it and could not rightly or justly be taken from them. In order to prevent the unjust taking of land by those who were stronger, individual property owners joined together to create governments, the original purpose of which was to protect the property of those who consented to join together and thus founded the government. His logic lies at the heart of subsequent theories of the "social contract", that is, that people consent to government and can therefore withdraw their consent and thereby act to change the government.

In the same vein, James Harrington, drawing from Machiavelli's claim that it was the possession of arms that assured people their rights as political actors, and writing in the same era, insisted that the right to bear arms was in turn 
dependent upon individuals' secure status as owners of their own land ${ }^{4}$. A monarch exercises limited sway over land-holding people, and they are not obliged to fight for him - their arms are their own. Forms of government roughly approximating democracy were possible only where people held land in relative equality. Under these circumstances, citizens possessed the human resources needed to disperse political authority in a diversified and balanced way and were thereby enabled to establish and preserve a stable polity. This in turn assured land holders security of tenure; they could pass their land on to their descendants, who were in turn assured not only of a place in political life, but also of the means through which to participate actively in it (Harrington, 1992; Pocock, 1975: 386-390).

In a pre-industrial society based on a subsistence economy, each lineage's rights over its own land enables its members to function as political actors. Under normal circumstances, resident lineages' relationships with the community's chief are defined by the lineages actual tenure over their land and possession of their own arms. In Micronesian societies, every adult male is a potential warrior, as well as a freeholder, and chiefs are obliged to listen and to heed. Throughout Micronesia public politics are conducted via councils composed of the heads of all the local lineages. Freedom of speech seems to be the norm, inasmuch as these councils engage in consideration of public business until all have expressed what they wish to say and then work hard to achieve consensus before any action is taken.

Finally, and most significantly, the tension between these two seemingly opposing political themes - of chiefly rights based on hereditary authority over land and lineage rights based on who works on the land - appears to reflect another central tenet of classical republican theory. By acknowledging their chief's authority over their land, Micronesian lineages assure themselves that he will also be responsible for protecting it. And because the chief is the leader of the entire community, and everyone in it acknowledges his authority, a threat to any one lineage's land means the potential mobilization, via the chief, of the entire community to defend it. In readily acknowledging the chief's authority over their land, Micronesians are not denying their own proprietary rights, but instead, assuring themselves of their government's protection of their lands. This is very much, if not precisely, the way Locke explained the nature of government.

It may well be that an interpretation based in western political theory does not adequately or truly represent Micronesians' understandings of their own political systems. But I believe that it does capture the underlying tension between the honor and deference chiefs receive, on the one hand, and the sense of individual and lineage autonomy, on the other, that together characterize Micronesian political dynamics. Tensions between the rights and responsibilities of government and the rights and responsibilities of individuals and families are characteristic of political life everywhere, and constitute the basic roots of the checks and balances that are the very stuff of politics. The essential similarities among what appear on the surface to be quite different forms of government are not always well understood by political scientists.

\section{Criticism of contemporary chieftainship}

\section{Stephanie Lawson's Tradition versus Democracy} in the South Pacific (1996) provides one of the most systematic critiques of the roles chiefs play in present-day Pacific islands governments. Lawson examines the contemporary workings of government in Fiji, Tonga, and Western Samoa, seeking to demonstrate that "traditionalist emphasis" on chiefs, monarchy, and matai in these societies enhances and enforces the continuing rule of elites. "The concept of tradition," she says,

" is one of the most important components of an ideological arsenal which has been used to counter the development of more democratic norms of political conduct and organization. »

In her view, indigenous claims about the continuing significance of tradition serve largely to preserve elite power and privilege against claims to "more extensive opportunities for participation" on the part of "those without traditionally derived political or social status" (1996: 5, Lawson's emphasis).

Underlying Lawson's treatment is a misapprehension about the presence and character of participatory politics as a key element in the dynamics of chieftainship. Arguing that "a substantial part of the history of democratic development in the West has been about depersonalizing political power, and vesting it in impersonal institutions," she contrasts the island polities in her case studies as marked by

« a much stronger personalized element in the assertion of tradition since its most authoritative bearers are those whose status is largely (although not exclusively) ascribed. » (1996: 12) 
Yet it is clear that in these societies, as in $\mathrm{Mi}$ cronesia, the most politically salient aspects of ascription are commonly seen in the manipulating (or selective reinterpretation) of genealogies after the fact of succession to a chiefly title. Indeed, I have had Micronesian chiefs explain to me that much of clanship's viability lies precisely in the broad net of men it makes eligible for titles, and this is borne out by ethnographies describing situations in which it is obvious that ascription is not the most salient factor in access to titles (Alkire, 1989: 44-46; Kiste, 1974: 52; Petersen, 1982). Lawson makes the error of granting unquestioning credence to these post facto claims, which in fact serve to legitimize, rather than prescribe, succession.

On the other hand, she also dismisses as little more than instrumentalist maneuvering the claims put forward by elites about their rights to run things, that is,

" the manipulation of tradition by indigenous elites in ways that enhance their own legitimacy by sanctifying the political order to which they owe their privilege. " (1996: 12)

Again, I see several problems with this portrayal. While it is certainly accurate in some senses, it is also a basic truism of social life that is hardly peculiar to Pacific islands politics; her assertions evoke Jeremy Bentham's powerful diatribe against "malefactors in high places" for whom "preservation of order is but keeping things in the state they are in: preservation of good order is keeping things in that state which, in proportion as it is good for the preservers, is bad for every body else" (Bentham, 1995: 112). Moreover, her analysis seems to indicate that the operation of political dynamics works only to justify the status quo, and rarely if ever constitutes a basic part of daily social life in communities full of people trying to get things done. Lawson finds it problematic that

"'traditionalism' can emerge and take on an explicitly ideological character that lends itself readily to instrumental manipulation »

and that

«tradition exhorts its participants to an attitude of reverence and duty toward the practices and values that have been transmitted from the past. " (1996: 17)

This echoes much too closely those classic political science attitudes describing

" traditional society, in which vast masses live an unpolitical life, embedded in customs and usages they need not understand. » (Merckl, 1967: 208)
Anyone who has spent much time in Pacific island societies knows how rarely one encounters unpolitical lives.

This outlook is, I think, the consequence of a perspective that overemphasizes the place of institutions in political life. In this approach, "democracy" is mostly about government. Yet, democracy is more appropriately - or at least productively - understood as something considerably more extensive than a type of government. Sheldon Wolin, who has devoted his distinguished career to the exploration of democratic politics, maintains that

"democracy needs to be reconceived as something other than a form of government. » (1996: 43)

\section{James Kloppenburg insists that}

" democracy is not now, nor has it ever been, primarily a question of representative institutions "

\section{and suggests instead that it be}

" conceived as a way of life rather than a way simply of managing conflict and preserving order. "(1995: 176)

When Lawson does tackle the issue of just what it is that constitutes democracy, she acknowledges that the gap between theory and practice

« is just as problematic in the West where democratic institutions have largely failed to deliver on the promise of greater equality for the mass of ordinary people. » (1996: 27)

If this is indeed the case (and I certainly believe that it is), then it seems to me her entire argument founders. We are asked to believe that Pacific island political cultures are predisposed toward personalized and authoritarian government and the instrumentalist manipulations of modern-day elites that prevent these societies from reaping the fruits of democratic institutions introduced by their erstwhile colonial rulers. But if the societies in which this western political form has arisen cannot themselves properly or fully implement it, then why are we blaming defects in the societies where it has been subsequently introduced for faults that appear to be inherent in the form itself?

It is precisely because the organization of daily life in most Pacific islands communities fosters an overwhelming amount of communication among groups of citizens that positions such as Lawson's are troubling. She is particularly unhappy with "claims of the 'democracy-as-indigenous' kind" and the question of whether the island nations have "pre-existing democra- 
tic traditions that can provide a better basis for contemporary political institutions than those imported from the West" (1996: 27-28). She explicitly denies this possibility, however, insisting "those principles that first gave democracy pride of place as the most desirable form of government are largely absent in the political practice" of the countries she examines (1996: 30), and railing against

"what some defenders of non-democratic systems in the South Pacific have done in promoting the validity of indigenous traditions against Western ideas about democracy. » (1996: 34)

From this perspective, it is specious to defend the political practices of these societies on grounds that they entail indigenous forms of democratic action or that they have the right to pursue their own political destinies regardless of what Westerners think best for them.

Lawson is hardly alone in her analysis, nor am I in my critique. Among the persistent complaints about shortcomings of the roles chiefly politics continue to play in present-day Fijian government, we find for example, Ratu Joni Madraiwiwi, who bears a high title and has also served as Fiji's Vice President, observing that there is

« little recognition or understanding by Fijians of the full implications of democracy " (2006: 295)

As I have argued, though, even scholars from socalled democracies are themselves often unable to grasp the full implications of the political systems they tout. Vijay Naidu believes that in Fiji

"Chiefly hegemony has been jeopardised with the divisions between and within confederacies, the vying for power among 'younger' chiefs, widespread disputes over succession to chiefly titles. » (2006: 300-301)

But it may well be that divisions, rivalries, and disputes are the lifeblood of any viable political system. And as Stewart Firth observes, the call for improved

" governance is part of a wider globalizing message preached by aid donors and international institutions, who see good governance as the best way to implement globalization and the free market, and who rather like to place the blame for failure not on global institutions but on national shortcomings in the developing countries. »(2006: 2)

There are in all these cases more complex processes, and more conscious political action, than Lawson and others seem to think. I am by no means suggesting that tradition and democracy are synonymous in Pacific island political cultures, but any work that is framed in terms of tradition versus democracy is apt to misunderstand a great deal of contemporary political life in the region. Despite the relative magnitude of most Pacific island nation-states' bureaucracies, their governments are not particularly oppressive. This must in some measure be attributed to a widespread indigenous commitment to participatory politics - that is, traditional democracy.

\section{Recent experience in Micronesia}

An array of colonial administrations have ruled the Micronesian islands. North of the equator, most of the island groups underwent successive rule by Spain, Germany, Japan, and the United States before achieving self-government and independence in the late twentieth century. Colonial rulers were ambivalent and unsystematic in their dealings with the chiefs, sometimes propping them up and at other times undermining them. An as yet unpublished paper has undertaken a comparative study of these processes in six different cases under American rule in the years following World War Two, providing useful historical perspective (Carucci et al., n.d.).

In the Marshalls, for instance, the U.S. administration established a Marshall Islands legislature. From the time it first convened in 1950, the body found itself engaged in heated debate over land rights, with paramount chiefs' claims "that as of right they owned all the land" set against commoners who were "stating that land was held in common." Disagreement about who wields authority over land continues (Carucci et al., n.d.: 7). In the Federated States of Micronesia's Yap state the government includes Councils of Traditional Leaders from both the island of Yap and from the outer islands, charged with matters of tradition and custom, areas which are broadly interpreted in contemporary life there. Many Yapese insist that their chiefly councils exercise veto power over all legislation proposed in the Yap state legislature that they, the councils themselves, consider to lie within the realm of authority over tradition, and chiefs continue to exercise considerable influence over who runs for elective office. But on the whole, Carucci concludes, the chiefs' roles remain in great flux (n.d.: 17)

Palau's constitution recognizes traditional leadership as possessing authority equal to constitutional law. The national legislature consults with the Council of Chiefs; chiefs comment formally on government actions.

"Legal arguments about the scope of traditional chiefly power often rise to Palau's Supreme Court [and] the two forms of governance are engaged in an ongoing dialogue and contest in managing Palau's political life. » (n.d.: 20) 


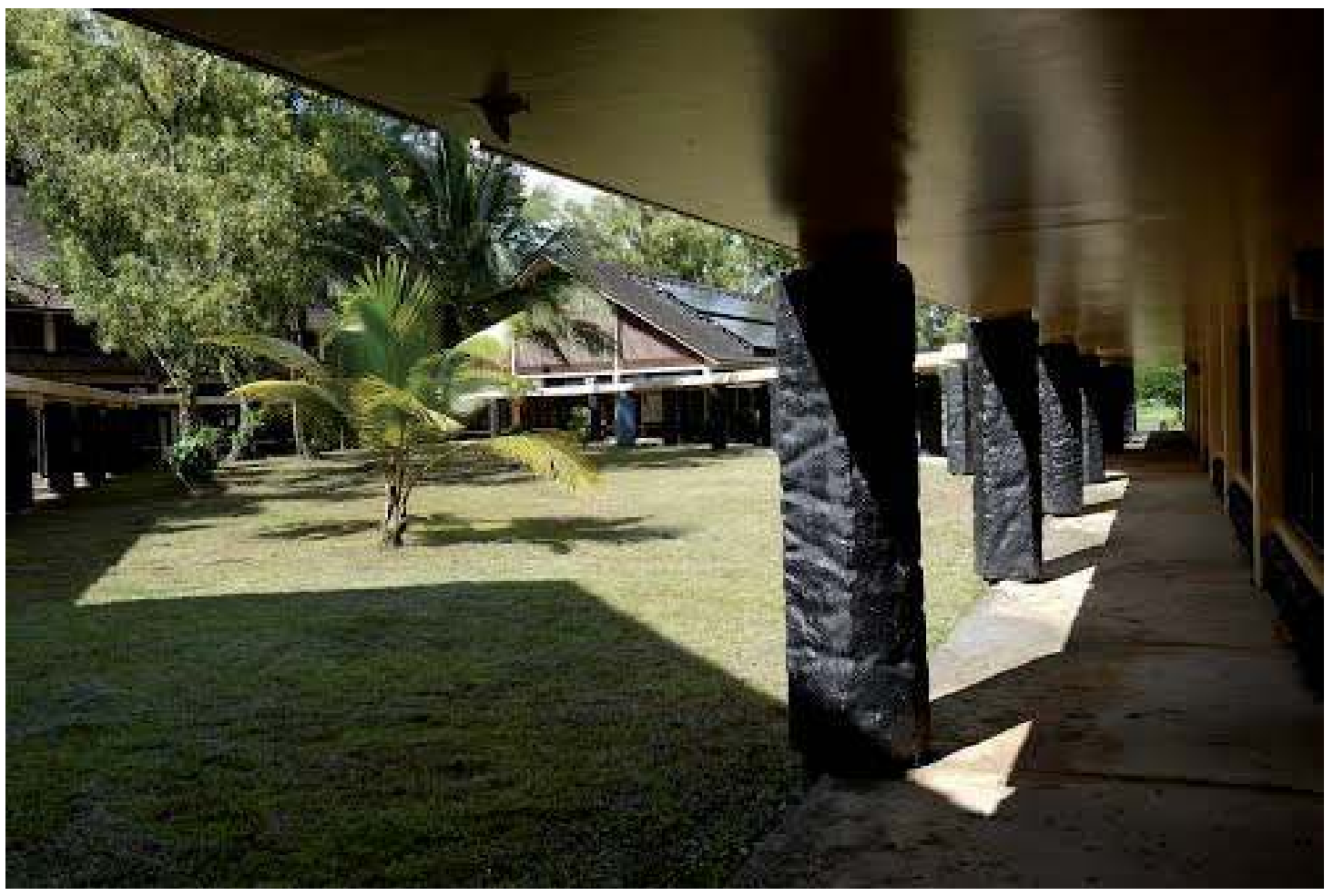

Рното 1. - The FSM national capital complex in Palikir, Pohnpei, constructed in the 1980 s, incorporates materials replicating the natural basalt columns used in the structures of Nan Madol, an ancient political center on Pohnpei, thus visually integrating traditional Micronesian forms with those of constitutional government (picture by the author)

Commenting on Micronesia as a whole, Carucci concludes

"Chiefdoms that remain effective in the modern context are not relics of the past, but systems that local people - as well as chiefly elites - find relevant and useful. This is not to say that melding tradition and modern governance is easy. Traditional authority today in the Pacific as elsewhere must engage with issues of human rights, voter equality, and women's rights. While the chiefly ideal emphasizes generosity and redistribution, the reality has changed. Transparency, nepotism, and corruption pose unique challenges when improprieties can be claimed as traditional rights. Yet Micronesia's chiefs have also used their authority in the service of the community by influencing public opinion and government policy. " (n.d.: 26)

\section{A Micronesian Chamber of Chiefs}

The history of proposals to create an explicit constitutional role for Micronesian chiefs provides perspective on the Micronesians' highly nuanced appreciation of checks and balances in their societies as a whole. In 1975, while the islands were still ruled by the United States as the Trust Territory of the Pacific Islands, a constitutional convention assembled in Saipan to draft a charter for a proposed new Micronesian nation-state. The 1975 ConCon's outcomes were decidedly mixed, reflecting competing outlooks on the islands' political status, and are only marginally relevant here. One item, however, is entirely relevant, Article V, Section 3 of the 1975 draft constitution specified that

"the Congress may establish, when needed, a Chamber of Chiefs. "

The negotiations entailed in getting this item into the draft were intricate and marked by great ambivalence on the part of many of the delegates. This draft was ultimately adopted as the Federated States of Micronesia's constitution in 1979, but tellingly, the FSM Congress did not opt to establish a chiefly chamber.

In 1990 the FSM convened a second constitutional convention (Petersen, 1993, 1994). One key proposed amendment was to establish (rather than merely allow establishment of) the Chamber of Chiefs (Petersen, 1997). As the convention progressed it became clear that there was considerable opposition to the proposal. It was deferred, taken up and deferred again, then reconsidered, amended, and after much skilled negotiation it finally passed by a $27-1$ vote. Opposition to it was initially mounted by both several state delegations and a number of individual delegates, but delegates were not merely divided among themselves in their 
attitudes toward the proposed Chamber; many were personally ambivalent, at times pressing for the Chamber and at other points voicing doubts about its potential to serve the Micronesian people. Opposition to the new Chamber was complex - there was palpable fear of the chiefs' political influence, but there was nearly equal desire to have them play a formal role in government as a check on the national congress. Delegates from every state, no matter what their position on the proposed amendment, insisted that no one in Micronesia - neither the Congress, the Convention, nor the people - could tell the chiefs what to do. But no one suggested that the chiefs would be ineffectual, nor that they were irrelevant or anachronisms. Rather, the crucial problem was the place that the chiefly system itself should hold in the contemporary Micronesian political scene.

Some very sophisticated points of view were expressed in testimony before the committee considering the proposal. The Chief Justice of Pohnpei State's Supreme Court argued that the institution of chieftainship itself would be threatened if chiefly roles were made subject to western legal precepts. It was exactly this sort of legislation, he said, that took away the powers of European monarchs. A Chuukese delegate pointed out that codification of chieftainship would be likely to freeze the relative rankings of titles, lineages, and clans in place and thus destroy the fluidity that characterizes the entire system.

The proposal was defeated overwhelmingly in the FSM's 1991 Constitutional Referendum. Popular opposition to the Chamber of Chiefs, however, is evidence not of chieftainship's declining significance in Micronesia, but of just the converse. The fact that in the traditional leaders' presence the ConCon delegates could not bring themselves to gainsay the chiefs exemplifies the dilemma. The chiefs retain tremendous influence, of various types and springing from multiple sources. In general, Micronesian communities have relied on the strengths of their chiefs to guarantee certain defensive functions - in relation to threats from both abroad and the supernatural world - and most people are thus inclined to support them. At the same time, however, people strongly resist any attempts on the part of the chiefs to interfere too much in the everyday, domestic sphere of community life. Micronesians accomplish these dual, contradictory tasks with political structures in which various leaders, factions, and communities ceaselessly compete with one another and thus serve to check overweening ambition and unwarranted attempts to exercise power.

As the entire thrust of the Chamber of Chiefs issue made clear, Micronesians have significant reservations about the power of their national government, generally perceiving the Congress as entirely too strong. Permitting the chiefs to take on a formal role in the national government would not only have enhanced their power, but decreased the dual character of the present-day Micronesian scene, which now functions with Congress on the one hand and traditional politics on the other. Keeping chiefs out of government seems to have been a deliberate means of preserving both their role as protectors of the people and the traditional structures of competing power blocs. For all that the FSM Constitution portrays itself as a guardian of Micronesian customs and traditions, the Micronesian people see their guarantees situated elsewhere, and aim to keep them there. It is solely from this perspective, I think, that we can understand why it was only in Kosrae, where there are no chiefs, that a majority actually voted in favor of the Chamber of Chiefs, while in Yap, which most observers would agree has the most viable traditional polity and the only state government with an official role for chiefs already in place, the Chamber received its greatest opposition.

\section{Conclusion}

Micronesian societies share common historical and cultural roots with Fiji and other eastern Oceanic communities. Chieftainship, land tenure, lineage structure, and the politics of everyday life are all closely entwined, and remain central to the survival of these new nation-states. Conversion to Christianity, colonial rule, and struggles for autonomy, self-rule, and independence have brought substantial changes to local political dynamics, but have not erased patterns that developed and proved effective over the course of millennia.

It is easy for political scientists and other scholars, along with international aid agencies and political operatives, to find fault in the processes of chiefly governance. For reasons that are shortsighted, chauvinistic, and perhaps narcissistic, too many observers tend to misunderstand democracy and democratic processes, often attributing a certain magical purity and effectiveness to them. In the Politics, a work that has certainly stood the test of time, Aristotle argued that in and of itself democracy is not an especially viable form of government. In his analysis, rather, the true value of democracy lies in the contributions it can make to mixed government, and held that it is in this combination of government by the one, the few, and the many that we find what he calls a successful government, that is a real "polity." Modern democratic states incorporate the one (the executive), the few (a legislature), and the many (the electorate), and have proved viable and resilient, if hardly free from strife, and in contemporary $\mathrm{Pa}$ cific island nation-states chieftainship constitutes a significant part of mixed governments. 
It is possible, I suppose, to imagine that good government is peaceful government, free from turmoil. But this does not strike me as especially plausible. Good government is a product of checks and balances, and of divisions of power, and depends on an element of struggle. Whether the procedures that organize productive opposition evolved in Westminster or were devised in Philadelphia, formal democracy does not really differ that much from the structures of Micronesian, Fijian and other Oceanic polities. They are all designed to be driven by opposition and competition, and competition begets cooperation; if they can do anything, chiefs and their people can, when necessary, cooperate. Chiefs, like any politicians, have been known to exploit and behave in ruthless fashion. But their status in their societies is in the end rooted in respect and affection, rather than the selfish and, sometimes, seemingly mindless individualism that increasingly characterizes modern capitalist worldviews. Chiefs and chieftainship, as part of a mixed government, offers the societies that retain them viable, humane, and familiar alternatives.

\section{BIBLIOGRAPHY}

Aristotle, 1958. The Politics, edited and translated by E. Barker, Oxford, Oxford University Press.

Bentham Jeremy, 1995. Rid Yourself of Ultramaria, in P. Schofield (ed.), Colonies, Commerce, and Constitutional Law: Rid Yourselves of Ultramaria and Other Writings on Spain and Spanish America, Collected Works of Jeremy Bentham, Oxford, Clarendon Press, pp. 3-194.

Carucci Lawrence, Suzanne Falgout and Lin Poyer, n.d. Micronesian Chiefs under American Rule: Military Occupation, Democracy, and Trajectories of Traditional Leadership, ms.

FiRTH Stewart, 2006. Introduction, in Stewart Firth (ed.), Globalisation and Governance in the Pacific Islands, Canberra, ANU E Press, pp. 1-6.

Goodenough Ward, 1951. Property, Kin and Community on Truk, New Have, Yale University Press, Yale University Publications in Anthropology 46.

Harrington James, 1992. The Commonwealth of Oceania, Edited by J.G.A. Pocock, Cambridge, Cambridge University Press.

KIrCH Patrick, 1989. The Evolution of the Polynesian Chiefdoms, Cambridge, Cambridge University Press.

Kloppenberg James, 1995. Democracy, in R.W. Fox and J. Kloppenberg (eds), A Companion to American Thought, Cambridge, Blackwell, pp. 173-177.
Lawson Stephanie, 1996. Tradition versus Democracy in the South Pacific, Cambridge, Cambridge University Press.

Locke John, 1960. Two Treatises of Government, Peter Laslett (ed.), New York, New American Library.

Machiavelli Niccolo, 1997. The Discourses on Livy, Translated by J.C. Bondanella and P. Bondanella, Oxford, Oxford University Press.

—, 1966. The Prince, Translated by Daniel Donno, New York, Bantam Books.

Madratwiwi Joni, 2006. Governance in Fiji, in Stewart Firth (ed.), Globalisation and Governance in the Pacific Islands, Canberra, ANU E Press, pp. 289-296.

VIJay Naidu, 2006. The State of the State in Fiji, in Stewart Firth (ed.), Globalisation and Governance in the Pacific Islands, Canberra, ANU E Press, pp. 297-315.

Petersen Glenn, 1993. Ethnicity and Interests at the 1990 Federated States of Micronesia Constitutional Convention. Regime Change and Regime Maintenance Discussion Paper Series 12, Research School of Pacific Studies, Australian National University.

—, 1994. Calm Before the Storm? The 1990 Federated States of Micronesia Constitutional Convention. The Contemporary Pacific 6 (2), pp. 337-369.

—, 1997. A Micronesian Chamber of Chiefs?, in G. White and L. Lindstrom (eds), Chiefs Today, Stanford, Stanford University Press, pp. 183-196.

—, 2006. Micronesia's Breadfruit Revolution and the Evolution of a Culture Area, Archaeology in Oceania 41, pp. 82-92.

—, 2009. Traditional Micronesian Societies, Honolulu, University of Hawai'i Press.

—, 2014. The Possibilities of Violence and the Skills to Avoid It: On Warfare and Its Absence in Traditional Micronesia, Anthropologica 56, 2, pp. 315-326.

Pocock J.G.H., 1975. The Machiavellian Moment, Princeton, Princeton University Press.

SAHLINs Marshall, 1958. Social Stratification in Polynesia. Monograph of the American Ethnological Society, Seattle, University of Washington Press.

—, 1968. Tribesmen, Englewood Cliffs, Prentice-Hall.

Wolin Sheldon, 1996. Fugitive Democracy, in S. Benhabib (ed.), Democracy and Difference, Princeton, Princeton University Press, pp. 31-45. 


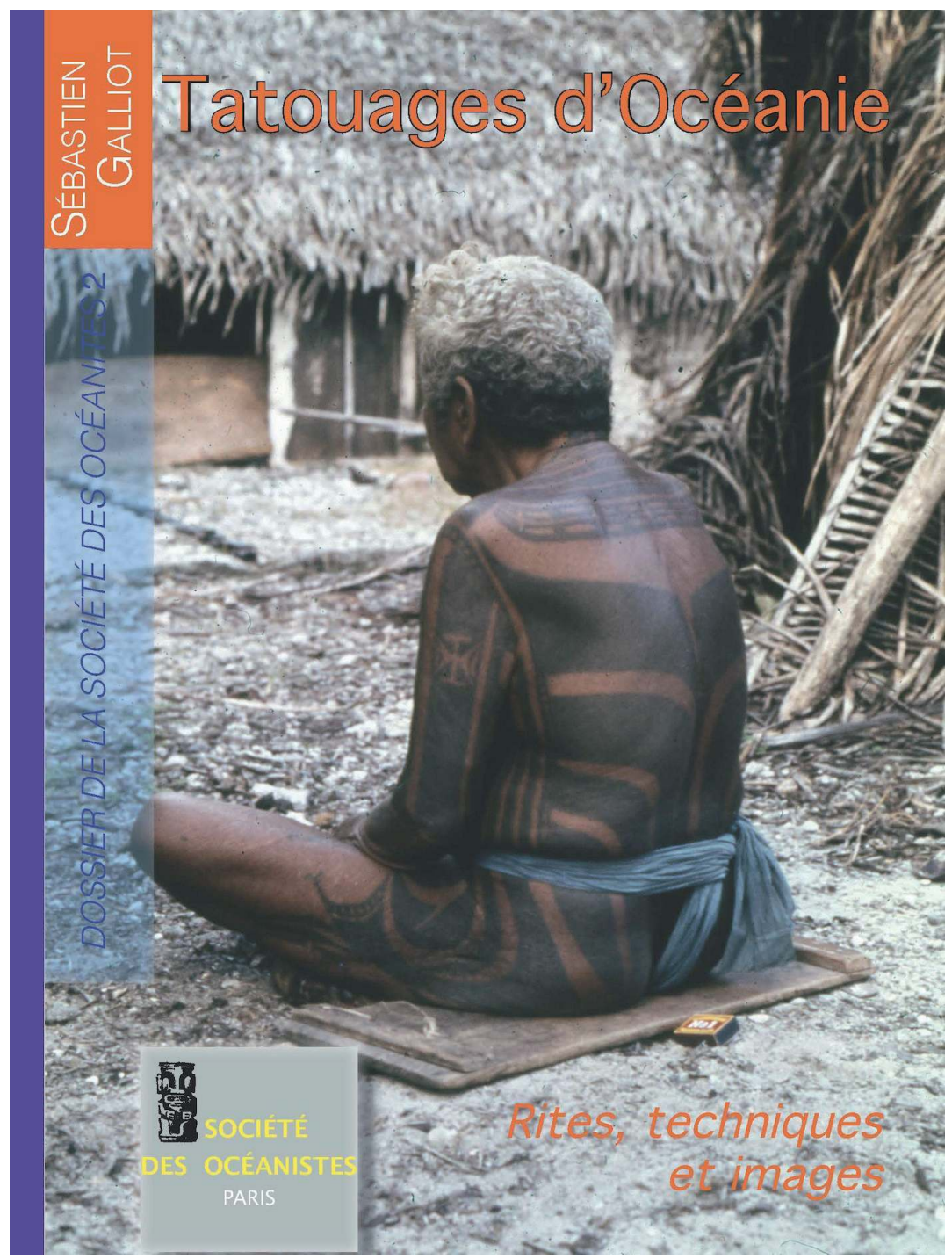

Pour accompagner l'exposition Tatoueurs, tatoués, du musée du quai Branly, la Société des Océanistes a le plaisir de vous annoncer la parution du second volume de la collection « Dossier de la Société des Océanistes » :

\section{Tatouages d'Océanie. Rites, techniques et images de Sébastien Galliot,}

36 p. avec de nombreuses illustration en couleur

ISBN version papier :

$978-2-85430-117-5$

$11,50 €$ pour la version papier

La version papier est disponible à la Société des Océanistes ou en ligne sur http://www.oceanistes.org/oceanie/spip.php?article3891
ISBN version électronique : 978-2-85430-119-9

9,99€ pour la version électronique La version électronique est disponible en ligne sur http://books.openedition.org/sdo/98 